\title{
Sclerochoroidal calcifications associated with early-onset calcium pyrophosphate deposition disease
}

\author{
Jacopo Ciaffi ${ }^{1}$ (D) Elena Borlandelli ${ }^{2} \cdot$ Luana Mancarella $^{1} \cdot$ Veronica Brusi ${ }^{1} \cdot$ Riccardo Meliconi $^{1,3} \cdot$ Francesco Ursini $^{1,3}$
}

Received: 11 April 2020 / Revised: 30 April 2020 / Accepted: 1 May 2020 / Published online: 16 May 2020

(C) International League of Associations for Rheumatology (ILAR) 2020

\section{Presentation}

A 40-year-old woman with calcium pyrophosphate deposition disease (CPPD) presented to the emergency department with intense migraine and vomiting. Computed tomography of the head was negative but bilateral calcifications of the globe were noted (Fig. 1a, b). Ophthalmologic examination with fundoscopy and optical coherence tomography confirmed the presence of multiple bilateral subretinal yellow-white lesions consistent with sclerochoroidal calcium pyrophosphate deposits. No eye treatment was needed and leflunomide, colchicine, and prednisone for CPPD were continued.

The patient was diagnosed with early-onset CPPD at the age of 26 on the basis of synovial fluid analysis from the knee joint revealing rhomboid-shaped calcium pyrophosphate crystals with weakly positive birefringence under compensated polarized light microscopy. During follow-up, x-rays of

Jacopo Ciaffi

jacopo.ciaffi91@gmail.com

Elena Borlandelli

elenaborlandelli@libero.it

Luana Mancarella

luana.mancarella@ior.it

Veronica Brusi

veronica.brusi@ior.it

Riccardo Meliconi

riccardo.meliconi@ior.it different sites showed intra-articular calcifications (Fig. 1c), and knee arthroscopy demonstrated white-clustered crystal deposits (Fig. 1d). The patient had normal renal function, and we ruled out Bartter syndrome, Gitelman syndrome, sarcoidosis, and disorders of calcium and phosphate metabolism. DNA sequence analysis excluded a mutation of the ANKH gene.

\section{Discussion}

Although retinal calcium deposits have rarely been described in young patients with chondrocalcinosis [1], a relationship between CPPD and sclerochoroidal calcifications has been suggested in literature [2], and our findings corroborate this possible association.

Francesco Ursini

francesco.ursini2@unibo.it

Medicine \& Rheumatology Unit, IRCCS Istituto Ortopedico Rizzoli (IOR), via Pupilli 1, 40136 Bologna, Italy

2 Radiology Unit, Department of Experimental, Diagnostic and Speciality Medicine, Sant'Orsola Hospital, University of Bologna, Bologna, Italy

3 Department of Biomedical and Neuromotor Sciences (DIBINEM), Section of Rheumatology, University of Bologna, Bologna, Italy 
Fig. 1 a, b computed tomography of the head showing bilateral calcifications of the globe; $\mathbf{c}$ x-ray showing acetabular labrum chondrocalcinosis; $\mathbf{d}$ arthroscopic demonstration of chondrocalcinosis

\section{Compliance with ethical standards}

\section{Disclosures None.}

\section{References}

1. Boutboul S, Bourcier T, Heligon JP, Houiller P, Ullern M, Abitbol M, Borderie V, Laroche L (2004) Familial pseudotumoral

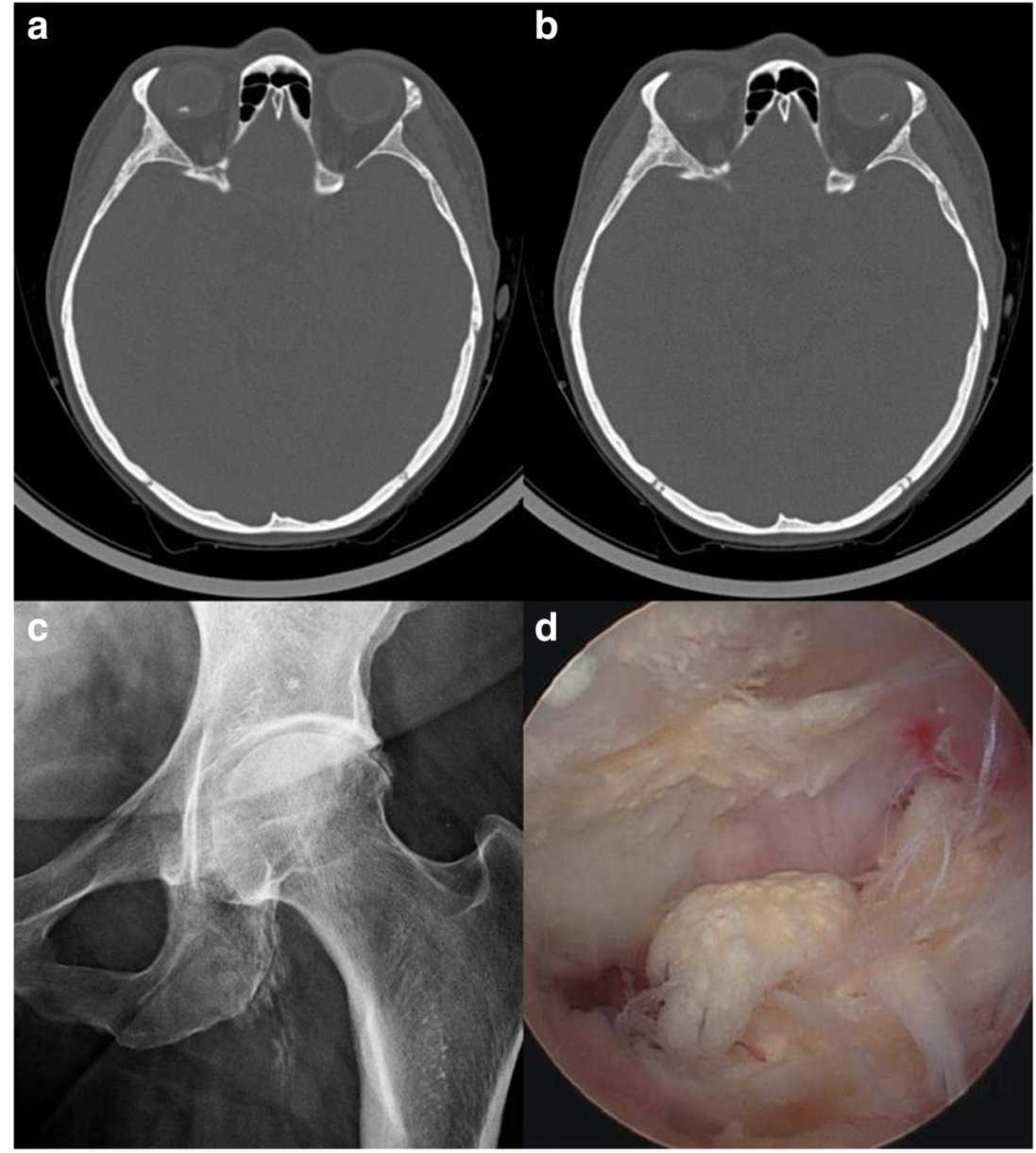

sclerochoroidal calcification associated with chondrocalcinosis. $\mathrm{Br}$ J Ophthalmol 88(8):1094-1095. https://doi.org/10.1136/bjo.2003. 039925

2. Shields JA, Shields CL (2002) CME review: sclerochoroidal calcification: the 2001 Harold Gifford Lecture. Retina. 22(3):251-261. https://doi.org/10.1097/00006982-200206000-00001

Publisher's note Springer Nature remains neutral with regard to jurisdictional claims in published maps and institutional affiliations. 